\title{
ANALISYS OF PAPER RESISTANCE TWO PRODUCT MATTPAPER
}

\section{ANALISIS KETAHANAN SOBEK DUA PRODUK KERTAS MATTPAPER}

\author{
Erry Tri Prabowo ${ }^{a^{*}}$, Efnyta Muchtar ${ }^{\mathrm{a}}$, Yessy Yerta Situngkir ${ }^{\mathrm{a}}$ \\ a Teknik Grafika, Politeknik Negeri Media Kreatif, Indonesia \\ *Email: errytriprabowo@gmail.com
}

\begin{abstract}
Paper is the most widely used print media, made with cellulose fibers derived from tree wood and non-fiber. The existence of paper is a tool that is quite important in human civilization and its needs continue to increase from year to year. The tear resistance of paper greatly affects the printing process. The value of tear resistance is influenced by several factors, namely the size of the fiber, besides that it is also influenced by the number of bonds between the fibers, grammar, humidity, moisture content, fiber direction, adhesive on the paper. The purpose of this final project is to determine the value of paper tear resistance which is better between two types of 120 gram Mattpaper paper products, namely New Victory Luxe and Nevia products and also to determine the effect of paper tear resistance on the printing process. The writing method used is descriptive method with data collection / observation, testing and literature techniques. Based on the results of the tear resistance test with the Elmendorf test method, which is to test the tear resistance of a paper, the tear resistance value of Nevia paper products is better than New Victory Luxe paper products.
\end{abstract}

\section{Keywords-Resistance, Paper, Mattpaper}

\begin{abstract}
Abstrak - Kertas merupakan media cetak yang paling banyak digunakan, dibuat dengan bahan serat selulosa yang berasal dari kayu pohon dan non serat. Keberadaan kertas menjadi sarana yang tergolong cukup penting dalam peradaban manusia dan kebutuhannya dari tahun ke tahun terus meningkat. Ketahanan sobek kertas sangat mempengaruhi proses cetak. Nilai ketahanan sobek dipengaruhi oleh beberapa faktor yaitu ukuran serat, selain itu juga dipengaruhi oleh jumlah ikatan antar serat, grammatur, kelembaban, kadar air, arah serat, perekat pada kertas. Tujuan penulisan Penelitian ini adalah mengetahui nilai ketahanan sobek kertas yang lebih baik antara dua jenis produk kertas Mattpaper 120 gram, yaitu produk New Victory Luxe dan produk Nevia dan juga untuk mengetahui pengaruh ketahanan sobek kertas
\end{abstract}


terhadap proses cetak. Metode penulisan yang digunakan adalah metode deskriptif dengan teknik pengumpulan data/observasi, pengujian dan kepustakaan. Berdasarkan hasil pengujian ketahanan sobek dengan metode pengujian Elmendorf yaitu menguji ketahanan sobek suatu kertas, nilai ketahanan sobek produk kertas Nevia lebih baik dibandingkan produk kertas New Victory Luxe.

\section{Kata Kunci-Ketahanan Sobek, Kertas, Mattpaper}

\section{PENDAHULUAN}

Kertas merupakan bagian penting bagi kehidupan manusia. Kertas bermanfaat sebagai media pencatatan dan penyebar luasan data dan informasi, keperluan pembungkusan, percobaan laboratoris, pemintal benang/tekstil dan tissue. Konsumsi kertas dapat menjadi salah satu ukuran kemajuan suatu bangsa. Sebagai gambaran, Amerika Serikat menduduki urutan pertama konsumsi kertas di dunia sebesar 345 $\mathrm{kg} / \mathrm{kapita}$, sedangkan Indonesia pada urutan ke-13 sebesar 30,1kg/kapita.

Keberadaan kertas menjadi sarana yang tergolong cukup penting dalam peradaban manusia dan kebutuhannya dari tahun ke tahun terus meningkat. Pada tahun 2004 kebutuhan konsumsi kertas mencapai 5,40 juta ton, sedangkan pada tahun 2005 konsumsi kertas meningkat hingga mencapai 6,45 juta ton. Pertumbuhan dalam dekade berikutnya diperkirakan $2 \%-3,5 \%$ per tahun atau membutuhkan kayu log dari lahan seluas $1-2$ juta hektar per tahun (Pusat Grafika
Indonesia, 2007). Hal ini merupakan peluang pasar yang baik bagi Indonesia dalam mengembangkan Industri pulp dan kertas.

Pada tahun 2016, kebutuhan kertas di Indonesia (lebih tepatnya Jawa Timur) mengalami peningkatan yang sangat signifikan yakni sekitar 10\% hingga 15\% dan juga mayoritas produksi industri itu diserap oleh percetakan buku sebesar 22 persen, koran atau surat kabar 15 persen sampai 17 persen, dan sisanya untuk industri pengemasan. Pada tahun 2017, Indonesia menjadi produsen kertas peringkat ke-6 terbesar dunia dan peringkat ke-9 untuk produsen pulp terbesar di dunia.

Dari sisi ekspor, Indonesia mampu mengekspor pulp sebesar 3,75 juta ton dengan nilai 1,85 miliar dolar AS dan mengekspor kertas sebesar 4,26 juta ton dengan nilai 3,76 miliar dolar AS. Adapun negara tujuan ekspor terbesar adalah Uni Eropa, Amerika Serikat, dan Tiongkok. Saat ini konsumsi kertas di dunia se-banyak 394 juta ton dan diperkirakan akan meningkat 
menjadi 490 juta ton pada 2020. Sementara di dalam negeri konsumsi kertas per kapita masih sangat jauh dari rata-rata konsumsi negara lainnya sehingga masih sangat potensial untuk berkembang.

Bahan utama pembuat kertas adalah dari bahan-bahan yang mengandung selulosa dan sampai saat ini masih lebih dari $90 \%$ industri pulp di indonesia berbahan baku kayu bulat, yang berasal dari hutan alam. Seluosa adalah suatu polisakarida yang tak larut dalam air dan merupakan zat pembentuk kulit sel tanaman. Selulosa terdapat lebih dari $50 \%$ dalam kayu, berwarna putih mempunyai kulit tarik yang besar.

Pulp diproduksi dari bahan baku yang mengandung selulosa. Selain terdapat dalam kayu, selulosa juga terkandung dalam beberapa tanaman lain seperti sekam padi. Sekam padi ini juga dapat menjadi bahan pembuatan pulp yang ramah lingkungan karena dapat mensubstitusi kayu dan memiliki manfaat lain seperti : mengurangi kerusakan lingkungan dan mengurangi tingkat CO2 di udara (Inovasi Indonesia, 2012).

Seiring dengan bertambahnya jumlah penduduk, bertambah pula kebutuhan manusia terhadap barang-barang kebutuhan sehari-hari termasuk diantaranya kertas. Kertas diperlukan tidak hanya sebagai alat tulis dan buku atau majalah tetapi juga sebagai tissu, pembungkus rokok, pembungkus makanan dan minuman.

Kertas juga dibutuhkan oleh berbagai industri sebagai alat promosi untuk menunjang jalannya industri yang dijalankan. Perusahaan - perusahaan kecil maupun besar saling berusaha untuk menjaga kualitas hasil cetakannya. Beberapa aspek dalam menjaga kualitas hasil cetakan harus diperhatikan, salah satunya yaitu bahan baku dengan kualitas yang baik agar menghasilkan cetakan dengan kualitas yang baik dan mutu yang tinggi.

Berdasarkan fakta diatas, penulis berharap penggunaan kertas dapat berkurang dan keadaan hutan di Indonesia menjadi stabil. Mengingat kebutuhan kertas terhadap perusahaan - perusahaan percetakan sangat banyak, penulis berharap suatu saat akan ada bahan baku yang dapat mengurangi kebutuhan kertas dari kayu yang berimbas kepada hutan di Indonesia.

Penggunaan kertas dalam industri juga mempengaruhi banyaknya kertas yang digunakan. Semakin banyaknya kesalahan dalam penggunaan kertas dalam industri, semakin banyak pula kebutuhan kertas yang diperlukan. Sering nya terjadi sobek kertas dalam proses cetak juga berpengaruh terhadap penggunaan kertas. Maka dari itu, penulis melakukan perbandingan ketahanan sobek kertas terhadap beberapa produk 
pembuat kertas. Penulis memilih jenis kertas berbahan dasar pulp kayu, yaitu Matt Paper dengan grammatur 120 gram dan mengggunakan produk yang digunakan oleh perusahaan di tempat penulis melakukan Penelitian.

Karena itu, penulis berencana untuk melakukan penelitian, "Perbandingan Sifat Ketahanan Sobek Kertas Mattpaper 120 gram Produk New Victory Luxe dengan Produk Nevia yang Digunakan Perusahaan PT. Aksara Grafika Pratama untuk Pencetakan Majalah Konstitusi”.

Penulis berharap dapat menemukan perbandingan, kelebihan dan juga kekurangan diantara kedua produk yang ada dari hasil pengujian yang nantinya akan dilakukan oleh penulis. Selain itu, penulis juga berharap Penelitian ini dapat memberikan informasi yang dibutuhkan oleh pihak - pihak yang terkait.

\section{Kertas}

Adanya kertas merupakan revolusi baru dalam dunia tulis menulis yang menyumbangkan arti besar dalam dunia peradaban. Kertas dikenal sebagai media utama untuk menulis, mencetak serta melukis dan banyak kegunaan lain yang dapat dilakukan dengan kertas (Anne Dameira, Kertas dan Karton, Basic Printing).

\section{Pengertian kertas secara umum}

Kertas adalah bahan baku utama dalam bisnis percetakan di dunia. Kertas adalah bahan baku utama dalam bisnis percetakan di dunia. Kertas merupakan lembaran tipis hasil kempa yang terbuat dari serat selulosa untuk membentuk jalinan yang tidak teratur dan ditambahkan bahan penolong untuk mendapatkan sifat - sifat tertentu dari kertas yang akan dibuat. Karton adalah kertas tebal yang mempunyai gramatur lebih berat.

Perbedaan gramatur/berat antara kertas, kertas karton, karton, dan board adalah sebagai berikut :
a. kertas
: $16-120 \mathrm{gr} / \mathrm{m}^{2}$
b. kertas karton
: $140-200 \mathrm{gr} / \mathrm{m}^{2}$
c. Karton
: $224-450 \mathrm{gr} / \mathrm{m}^{2}$
d. board
: $>500 \mathrm{gr} / \mathrm{m}^{2}$

Kertas mempunyai banyak fungsi dalam penggunaannya. Fungsi paling mendasar dari kertas adalah untuk menyampaikan informasi melalui media cetak seperti buku, majalah, koran dan sebagainya. Tidak kalah penting kertas juga banyak digunakan untuk kemasan, untuk mewadahi dan melindungi produk dari kerusakan-kerusakan sehingga lebih mudah disimpan, diangkut dan dipasarkan.

\section{Bahan Baku Pembuatan Kertas}

Penyediaan bahan baku adalah proses pengolahan bahan mentah menjadi bahan baku yang siap digunakan dalam proses pembentukan kertas. Jenis dan ukuran bahan baku mempengaruhi ketahanan sobek pada 
kertas. Adapun bahan baku untuk pembuatan kertas adalah :

\section{a. Serat Selulosa}

Sejalan dengan perkembangan teknologi, hingga saat ini secara global hampir 100\% bahan mentah untuk pembuatan serat selulosa (bahan baku). Bahan mentah pada umumnya menggunakan dalam pembuatan serat selulosa. Kayu mempunyai keunggulan dibandingkan dengan bahan bukan kayu seperti jerami padi, ampas tebu, bambu dan lainnya. Selulosa adalah golongan polisakarida dan merupakan polimer yang kompleks, terbentuk dari alam dengan susunannya terdiri dari unsur karbon. hidrogen dan oksigen.

Serat memiliki beberapa sifat, yaitu :

1. Bersifat hygroskopis.

2. Tahan terhadap asam dan basa kuat dalam konsentrasi yang lemah.

\section{Bersifat transparan.}

Pada saat ini, pulp dibuat secara mekanik, semi mekanik, dan cara kimia yang tujuannya adalah untuk mendapatkan serat-serat halus dan menghilangkan lignin atau komponen lainnya selain serat selulosa.

Selulosa merupakan sumber polisakarida atau bahan pakan sumber energi untuk menghasilkan VFA (Volatile Fatty Acid). Ikatan lignin sangat kuat, terlebih pada tanaman yang telah berbuah (jerami padi, ampas tebu) akan memiliki lignin yang lebih banyak.

Kertas dapat dibuat dari beberapa tumbuhan yang berbeda dan mempunyai kadar serat selulosa yang tergantung dari sumber tanamannya. Seperti:

1. Faktor kandungan serat selulosa.

2. Faktor mendapatkan bahan mentah.

Di dalam serat selulosa terdapat senyawa yang bernama Hemiselulosa. Hemiselulosa merupakan suatu polisakarida lain yang terdapat dalam tanaman dan tergolong senyawa organik. (Casey, 1960) menyatakan bahwa hemiselulosa bersifat non-kristalin dan tidak bersifat serat, mudah mengembang. Karena itu, hemiselulosa sangat berpengaruh terhadap bentuknya jalinan antara serat pada saat pembentukkan lembaran, lebih mudah di hidrolisis dengan asam.

\section{b. Bahan Non Serat}

Bahan non serat juga disebut bahan penolong, yang digunakan untuk mendapatkan sifat-sifat khusus pada kertas dalam hubungannya dengan pembuatan dan pengunaan kertas. Bahan non serat antara lain:

\section{Bahan Pengisi}

Bahan pengisi merupakan bahan non serat yang ditambahkan pada pembuatan kertas. Fungsinya secara umum adalah mengisi rongga udara antara serat dengan serat. Fungsi bahan pengisi secara khusus yaitu : 
a) Meningkatkan nilai opasitas

b) Memperbaiki kerataan permukaan kertas dengan mengisi lembah-lembah kosong pada permukaan kertas.

c) Meningkatkan kecerahan kertas (brightness)

d) Memperbaiki daya cetak permukaan kertas

e) Memperbaiki daya serap kertas terhadap zat cair

f) Mengatur berat kertas

Bahan pengisi yang berlebihan akan terjadi :

a) Kertas menjadi rapuh

b) Kertas mudah mengalami pendebuan

c) Mengurangi sifat ketahanan tarik kertas

d) Kertas menjadi kaku

Bahan pengisi yang digunakan :

a) Kaolin

b) Kalsium karbonat

c) Titan dioksida

Penggunaan bahan pengisi tergantung kepada jenis kertas yang dibuat, misalnya kertas HVS menggunakan bahan pengisi Kaolin. Untuk jenis-jenis kertas yang berhubungan dengan segi keamanan (security) menggunakan Titan dioksida.

2. Bahan Perekat

Bahan perekat memiliki fungsi secara umum, yaitu :

Untuk merekatkan serat dengan serat, serat dengan bahan pengisi, sehingga teradi jalinan yang kuat dan kompak. Serat-serat yang digunakan untuk kertas (selulosa), sebetulnya tanpa diberi bahan perekat mereka sudah saling mengkait. Untuk keperluan khusus seperti kertas yang akan digunakan sebagai alas mencetak biasanya kertas tersebut diberi bahan perekat (sizing) supaya kertas tidak melunak pada waktu terkena tinta cetak.

Selain itu, kegunaan bahan perekat pada kertas untuk memperkuat dan mengawetkan. Pemberian bahan perekat pada kertas ada dua cara, yaitu :

a) Perekat Dalam (Internal Sizing), yaitu perekat yang diberikan pada saat pembuatan bubur kertas. Fungsi perekat dalam pada pembuatan kertas yaitu :

1) Untuk menambah ketahanan kertas terhadap air, namun tidak berarti menjadi tahan air akan tetapi meningkatkan kekuatan penyerapan minyak pada tinta cetak kedalam kertas.

2) Meningkatkan ketahanan lipat.

3) Meningkatkan kestabilan ukuran kertas.

4) Meningkatkan kekuatan kertas secara umum, seperti ketahanan sobek, ketahanan cabut dan lainnya.

b) Perekat Luar (External Sizing), yaitu perekat yang diberikan setelah kertas/karton sudah menjadi lembaran. Fungsi perekat luar pada pembuatan kertas yaitu :

1) Memperbaiki sifat permukaan kertas yaitu kerataan dan kelicinan. 
2) Menambah ketahanan terhadap cabutan.

3) Menambah ketahanan terhadap zat cair.

4) Mengurangi pendebuan.

5) Meningkatkan kestabilan ukuran kertas. Bahan Perekat yang digunakan :

a) Rosin

b) Wax

c) Starch

3. Bahan Pewarna

Bahan pewarna berfungsi untuk menambah kecerahan suatu kertas, memberikan kesan agar kertas tersebut lebih menarik, dan untuk membuat kertaskertas khusus yang berhubungan dengan segi keamanan (security).

Contoh bahan pewarna yang digunakan :

a) Methil violet.

b) OBA (Optical Brightness Agent).

c) Zat warna dai, digunakan untuk kertas berwarna.

\section{Jenis-Jenis Kertas}

a. Berdasarkan keadaan permukaan

Berdasarkan keadaan permukaan, kertas terbagi menjadi beberapa jenis, yaitu:

1. Kertas tak berlapis (uncoated paper)

Merupakan kertas yang tidak diberikan lapisan dengan ciri - ciri permukaan yang berpori - pori dan mempunyai daya serap tinta yang tinggi. Contoh : kertas Koran, HVS, HHI.

2. Kertas berlapis (coated paper)

Merupakan jenis kertas yang pada permukaannya diberikan lapisan. Lapisan tersebut terdiri dari zat kapur (bahan pengisi) dan perekat. Kertas jenis ini mempunyai karakter permukaan yang halus, licin, mengkilat, dan mempunyai daya serap tinta yang rendah. Huruf dan image terlihat lebih tajam dan detail karena tinta tidak bleber. Kertas ini sukar untuk ditulisi karena permukaannya yang licin. Contoh : kertas art paper/kunstdruk, Mattpaper.

b. Berdasarkan jenis serat

1. Kertas mengandung kayu

Kertas jenis ini merupakan jenis kertas yang disamping masih mengandung serat selulosa, tetapi masih mengandung unsur - unsur kayu lainnya seperti lignin dan getah.

Lignin adalah suatu polimer komplek dengan berat molekul tinggi. Sifat senyawa ini sangat stabil dan sulit untuk dipisahkan. Lignin bersama hemiselulosa membentuk lem alami yang menjadi perekat yang membuat kokoh sifat mekanik kayu tersebut.

Ciri - ciri kertas ini antara lain:

a) Dibuat dari serat mekanik

b) Tidak tahan disimpan lama

c) Mudah menguning jika kena sinar matahari

d) Nilai opasitasnya tinggi 
2. Kertas bebas kayu

Kertas jenis ini merupakan jenis kertas yang terbebas dari unsur kayu kecuali serat selulosa. Ciri - cirinya antara lain:

a) terbentuk dari serat kimia

b) tahan disimpan lama

c) tidak mudah menguning

d) nilai opasitasnya rendah

c. Berdasarkan penggunaannya

1) kertas cetak, seperti: HVO, Koran, Art paper, Mattpaper.

2) kertas tulis, seperti: HVS, kertas gambar

3) kertas bungkus, seperti: Cassing, kertas sampul, kertas Samson

4) kertas khusus, seperti: kertas uang, kertas rokok, kertas tissue

\section{Sifat-Sifat Kertas}

a. Sifat Fisik

\section{Berat dasar dan ketebalan}

Berat kertas adalah masa lembaran kertas atau lembaran karton dalam gram dibagi dengan satuan luasnya dalam meter persegi $\left(\mathrm{gram} / \mathrm{m}^{2}\right)$, diukur pada kondisi standar. Ketebalan kertas adalah jarak tegak lurus antara kedua permukaan kertas diukur pada kondisi standar $\left(\mathrm{gram} / \mathrm{m}^{2}\right)$.

2. Ketahanan Tarik dan Regangan Ketahanan tarik adalah daya tahan lembaran kertas atau karton terhadap gaya tarik yang bekerja pada kedua ujung kertas atau karton tersebut. Ketahanan tarik dihitung berdasarkan nilai rata-rata pembacaan skala ketahanan tarik dalam $\mathrm{kg}$ gaya $(\mathrm{k} \mathrm{N} / \mathrm{m})$, sedangkan daya regangan dihitung berdasarkan nilai rata-rata pembacaan skala daya regang, dinyatakan dalam bentuk persen $(\%)$ dan diukur pada kondisi standar. Ketahanan tarik juga berpengaruh pada sifat regangan dari kertas tersebut. Pada cetak Web Offset kertas mengalami proses penarikan dan dengan sendirinya terjadi pemanjangan bentuk ukuran kertas.

3. Kehalusan/kekasaran permukaan

Sifat permukaan kertas atau karton yang ditetapkan dengan cara menggunakan derajat bebasnya permukaan dari ketidakrataan. Nilai kekasaran permukaan kertas dinyatakan dalam bentuk $\mathrm{cm}^{3} / \mathrm{m}^{2}$.

4. Keporian

Sifat kertas/Koran yang mempunyai banyak atau setidaknya rongga udara. Keporian ditetapkan dengan metode kelicinan yaitu berdasarkan jumlah waktu yang diperlukan untuk mengalirkan $10 \mathrm{ml}$ udara pada permukaan yang diuji.

5. Daya Serap Air dan Minyak

Daya serap air adalah jumlah gram air yang diserap oleh satu meter persegi 
lembaran kertas atau karton dalam waktu penyerapan selama beberapa detik, diukur pada kondisi standar dalam satuan gram $/ \mathrm{m}^{2}$. Kondisi standar ruang pengujian dengan suhu $23^{\circ} \mathrm{C}$.

Daya serap minyak yaitu kemampuan pori-pori kertas/karton untuk menyerap zat cair. dihitung berdasarkan kebalikan panjang hasil cetakan pada jalur uji dalam satuan $1000 / \mathrm{mm}$.

6. Ketahanan Cabut

Yaitu sifat kuat atau lemahnya permukaan kertas/karton karena gaya cetak atau tarikan tinta cetak (poise/detik). Faktor-faktor yang mempengaruhi terjadinya ketahanan cabut : kadar air dalam kertas, kelembaban ruang, kelengketan tinta cetak, kekentalan tinta cetak, kecepatan mesin cetak, tekanan cetak, lemahnya perekat dalam kertas, dan serat pendek.

\section{Ketahanan Sobek}

Ketahanan sobek adalah gaya dalam milinewton $(\mathrm{mN})$ yang diperlukan untuk menyobek kertas pada kondisi standar $\left(23^{\circ} \mathrm{C}\right)$. Indeks sobek nya adalah ketahanan sobek kertas dalam milinewton dibagi dengan gramatur kertas dalam gram permeter persegi. Standar ini menetapkan cara uji ketahanan sobek lembaran kertas menurut metode Elmendorf. Standar ini tidak berlaku untuk karton gelombang, tetapi dapat untuk komponen-komponennya.

8. Ketahanan Lipat

Merupakan sifat yang menunjukkan jumlah lipat yang dapat dicapai oleh suatu kertas/karton hingga putus.

9. Ketahanan Retak

Sifat kertas/karton yang menunjukkan banyaknya gaya yang diperlukan untuk meretakkan selembar kertas atau karton dalam kilopaskal $(\mathrm{kPa})$.

10. Kekakuan (stiffness)

Sifat melengkungnya kertas/karton dengan cara mengukur gaya yang diperlukan pada ukuran tertentu dan sudut yang telah ditentukan $(\mathrm{mN})$. Satuan dinyatakan dalam bentuk panjang kedua sisi rentangan yang melengkung ketika mencapai sudut putaran kritis dan dinyatakan sebagai panjang kritis.

11. Pendebuan

Sifat permukaan kertas/karton yang berasal dari partikel-partikel atau seratserat yang tidak terekat maupun debu yang terdapat pada permukaan contoh uji tersebut (skala IGT).

b. Sifat Kimia

1) Keasaman $(\mathrm{pH})$ 
Yaitu konsentrasi ion Hidrogen dalam suatu larutan kertas/karton. Dapat ditentukan dengan pengukuran konsentrasi jumlah ion dari larutan hasil ekstrak contoh kertas.

2) Kadar Air dan Kadar Abu

Kadar Air yaitu jumlah kadar air yang ada pada kertas/karton dan dapat ditetapkan dengan cara mengeringkan contoh uji pada suhu diatas titik didih air $\pm 105^{\circ} \mathrm{C}$, setelah itu ditimbang pada neraca analitik sampai diperoleh berat konstan.

Kadar Abu yaitu jumlah sisa contoh kertas/karton yang tinggal setelah pembakaran pada suhu $925 \pm 25^{\circ} \mathrm{C}$ dan dinyatakan dalam persen (\%).

\section{3) Scumming}

Yaitu pengotoran pada bagian tidak mencetak karena kertas menimbulkan emulsi antara air dan tinta cetak. Jika ada bagian hitam pada jalur alumunium, maka kertas yang diletakkan pada jalur alumunium pada posisi hitam tersebut dapat menyebabkan scumming.

4) Jenis Serat

Yaitu untuk mengetahui apakah suatu kertas/karton terbuat dari serat mekanik atau serat kimia dengan cara meneteskan kertas/karton dengan larutan phloroglucin (1 gram), dan dicampur dengan alcohol sebanyak 25cc dan $\mathrm{HCl}$ sebanyak 12,5cc. c. Sifat Optik
1) Opasitas

Yaitu sifat lembaran kertas yang dapat menghalangi tembusnya cahaya sehingga meghalangi penglihatan tembus melalui lembaran terhadap benda yang ada dibaliknya. Dilakukan dengan cara perbandingan antara faktor pantul (Ro) dengan faktor pencahayaan intrinsik (Roo) dan dinyatakan dalam persen (\%).

2) Kecerahan

Yaitu ukuran untuk membedakan derajat putih kertas/karton dalam jenis yang sama dengan memakai cahaya/penerangan. Kecerahan dapat diukur dengan alat Data Color Elrepho 2000 dan dinyatakan dalam bentuk persen $(\%)$.

3) Warna

Yaitu bagian cahaya yang dipantulkan dari permukaan kertas/karton sehingga menimbulkan kesan tertentu, misalnya biru, kuning, dan sebagainya. Diukur bersamaan dengan pengukuran kecerahan dan juga dalam bentuk persen (\%).

\section{Persyaratan Umum Kertas Cetak}

Sebuah percetakan akan memberikan beberapa persyaratan umum terhadap kertas yang akan digunakan dan disesuaikan dengan pertimbangan tertentu, mulai dari penggunaan akhir barang, harga barang dan kemampuan cetaknya.

Maka dari itu, percetakan akan mengajukan beberapa syarat, yaitu: 
a. Formasi/keawanan kertas harus baik

b. Keseragaman (terutama berat/tebal)

c. Warna dan derajat putih

d. Permukaan harus datar

e. Beda kedua sisi tidak terlalu besar

f. Mempunyai kekakuan (stiffness) yang cukup

Selain itu, suatu percetakan juga akan meminta jaminan kepada pabrik kertas tersebut agar :

a. Partai kertas yang diterima harus terbungkus baik dengan pembungkus yang kedap uap/udara atau tahan air

b. Partai kertas yang diterima dalam keadaan permukaan datar dan di dalam keadaan normal (suhu dan kelembaban) tetap datar.

c. Lembar kertas dipotong menurut segi empat yang benar-benar tepat dan lurus dengan arah serat yang dikehendaki.

d. Tidak terdapat kerusakan/ cedera pada lembar-lembar kertasnya, jika dalam bentuk rol, tetap rata dan sirkulasi.

e. Berisi jumlah yang tepat untuk setiap rimnya.

\section{Kertas Mattpaper}

Merupakan salah satu jenis kertas coated atau kertas yang memiliki lapisan pada permukaannya. Diantara jenis kertas coated antara lain adalah Mattpaper yang memiliki tingkat kehalusan rendah, maka sering disebut juga dengan "semi - gloss" atau gloss ringan".
Kertas coated yang dilapisi oleh pigmen diikat oleh bahan perekat (sizing) maka permukaan kertas akan semakin halus dan mengkilap karena pemantulan cahaya yang beraturan membuat mata kita melihat kilauan/pantulan cahaya tersebut dengan jelas. Semakin halus (glossy) permukaan kertas maka akan semakin sempurna pantulan cahayanya.

Sedangkan Mattpaper adalah jenis kertas yang termasuk jenis yang dilapisi, akan tetapi kertas ini memiliki permukaan yang matt (tidak terlalu mengkilap), permukaannya semi gloss. Ini sangat cocok untuk mencetak isi buku seperti katalog, majalah, company profile, buku kenangan, buku tahunan, poster, brosur, kalender dan sebagainya.

\section{Pengertian Ketahanan Sobek}

Ketahanan sobek adalah gaya dalam gram gaya (gf) atau milinewton (mn) yang diperlukan untuk menyobek kertas pada kondisi standar (SNI 14-0091-1998). Sedangkan indeks sobek lembaran kertas merupakan hasil bagi dari ketahanan sobek dengan grammatur. Kekuatan sobek lebih dipengaruhi oleh Ukuran serat, selain itu juga dipengaruhi oleh jumlah ikatan antar serat, grammatur, kelembaban, kadar air, arah serat, perekat pada kertas. Ikatan antar serat hanya meningkatkan kekuatan sobek sampai tingkat tertentu. 


\section{METODE PENELITIAN}

Metode yang digunakan dalam menyusun penelitian ini adalah metode deskriptif, yaitu dengan cara memaparkan informasi - informasi faktual yang diperoleh dari observasi yang didapat dan dilihat di tempat praktek industri dan pengujian di laboratorium Politeknik Negeri Media Kreatif Jakarta.

\section{Faktor-Faktor yang Mempengaruhi Ketahanan Sobek}

Adapun beberapa faktor yang dapat mempengaruhi ketahanan sobek suatu kertas, yaitu :

\section{a. Ukuran Serat}

Kertas yang memiliki serat panjang akan memiliki ketahanan sobek lebih tinggi dari pada kertas yang memiliki serat pendek. Kertas yang memiliki lebih banyak ikatan antar serat juga memiliki ketahanan sobek lebih tinggi dari pada yang hanya memiliki sedikit ikatan antar serat. Jumlah serat juga akan mempengaruhi densitas, gramatur dan kelenturan kertas. Kertas yang kaku akan memberikan tekanan ke atas serat pada daerah/tempat yang kecil, tetapi kertas yang sifatnya lentur akan menyebarkan tekanan di atas daerah yang lebih luas.

b. Jumlah serat selulosa

Sifat ketahanan sobek dipengaruhi oleh jumlah selulosa yang terdapat pada lembaran kertas. Sehingga memiliki lebih banyak ikatan antar serat. Ikatan serat juga mempegaruhi nilai ketahanan sobek kertas. Hal tersebut didukung oleh pernyataan Mulyana (2007) bahwa bahan yang mengandung selulosa yang lebih banyak akan menghasilkan lembaran kertas yang memiliki ketahanan sobek yang lebih tinggi, sedangkan yang lebih sedikit akan memiliki ketahanan sobek yang lebih rendah.

\section{c. Gramatur}

Berat kertas dengan jenis yang sama akan mempengaruhi kekuatan sobek. Semakin berat kertas maka semakin kuat ketahanan sobeknya. Contohnya yaitu kertas Mattpaper 100 gram dengan Mattpaper 120 gram.

\section{d. Perekat}

Perekat akan mengisi ruangan antar ikatan serat. Apabila perekat ditambahkan dengan homogen, maka kertas akan menjadi kuat dan tidak mudah sobek.

e. Kadar air

Kadar air merupakan jumlah uap air yang ada pada ikatan serat. Kadar air juga mempengaruhi ketahanan sobek suatu kertas. Semakin banyak jumlah kadar air yang ada pada kertas, maka kertas akan mudah sobek dan sebaliknya.

\section{f. Kelembaban}

Kelembaban udara dapat mempengaruhi kadar air pada kertas. Apabila nilai kelembaban di udara tinggi maka kertas akan menyerap air dari udara karena sifat 
hygroskopis dari serat, akibatnya kertas akan mempunyai kadar air tinggi sehingga kertas mudah sobek. Untuk mengukur kelembaban udara digunakan alat Hygrometer. Alat ini dapat juga digunakan untuk mengukur kelembaban udara pada lembaran kertas.

g. Arah Serat

Arah serat mempengaruhi ketahanan sobek pada kertas. Terdapat dua arah serat, yaitu :

a. Cross Direction (CD), yaitu arah yang memotong ikatan serat. Arah serat CD biasanya memiliki nilai ketahanan sobek lebih tinggi.

b. Machine Direction (MD), yaitu arah yang memisahkan ikatan serat. Arah serat ini biasanya memiliki nilai ketahanan sobek lebih rendah.

Pengujian ini penulis lakukan dibawah Pranata Laboratorium Pendidikan (PLP) di Laboratorium Pengujian Bahan Grafika Politeknik Negeri Media Kreatif Jakarta. Penulis melakukan pengujian untuk mendapatkan data yang akan dianalisa pada bab selanjutnya sehingga masalah pada Penelitian ini dapat terjawab sesuai dengan data-data yang akurat dan diinginkan.

\section{Alat yang Digunakan}

A. Alat uji ketahanan sobek menurut Elmendorf yang dilengkapi dengan :

1. Alat penjepit yang terdiri dari sebuah penjepit statis dan sebuah penjepit yang dapat bergerak bersama sektor pendulum.
2. Sektor pendulum dengan kapasitas 2000 $\mathrm{mN}, 4000 \mathrm{mN}, 8000 \mathrm{mN}, 16000 \mathrm{~N}, 32000$ mN, dan 64000 mN (200 gf, 400 gf, 800 gf, 1600 gf, 3200 gf, 6400 gf).

3. Pisau untuk penyobekan awal

4. Alat penahan sektor pendulum.

5. Jarum penunjuk dan skala ketahanan sobek

B. Alat pemotong kertas :

1. Kacip

2. Gunting/cutter

C. Penggaris

D. Pensil/pulpen

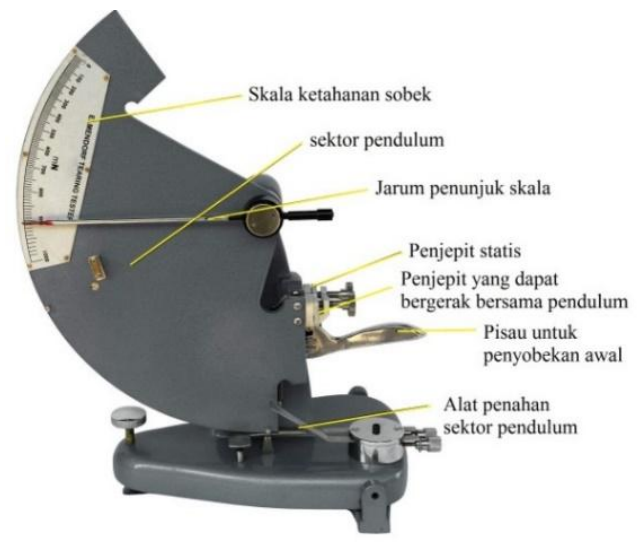

Gambar 1. Tearing Tester/Alat Uji Ketahanan Sobek

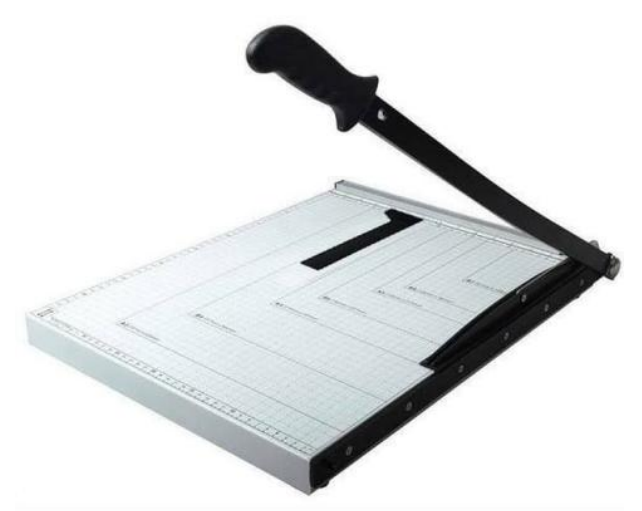

Gambar 2. Alat Pemotong Kertas (kacip) 


\section{Bahan yang Digunakan}

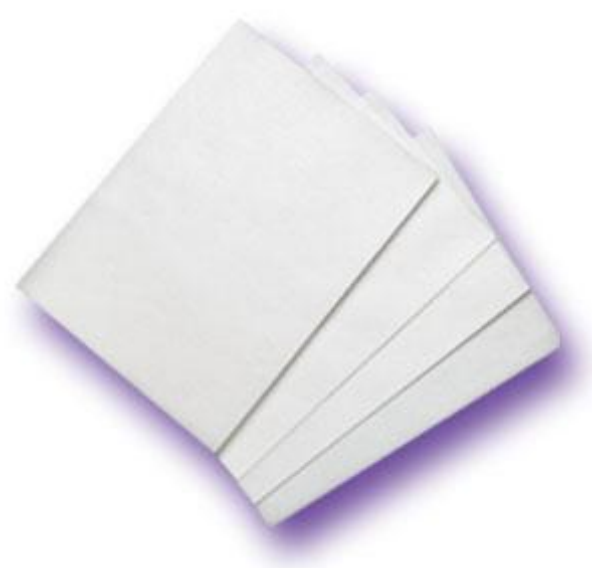

Gambar 3. Sampel Kertas

Kertas Mattpaper 120 gram produk

New Victory Luxe dan Nevia masing-masing sebanyak 100 lembar untuk arah serat MD dan CD. Ukuran kertas yaitu 64 mm x 76 mm.

\section{Rumus Perhitungan Ketahanan Sobek}

Ketahanan sobek $=\frac{16 \times A}{B}$

Ketahanan sobek rata-rata $(\bar{x})=\frac{\Sigma \mathrm{x}}{n}$

$\pm \mathrm{SD}=\sqrt{\frac{\sum(\mathrm{x}-\bar{x})^{2}}{n-1}}$

$\%$ Variasi $=\frac{ \pm S D}{\bar{x}} \times 100 \%$

Keterangan :

$16=$ kapasitas bandulan

$\mathrm{A}=$ pembacaan skala rata - rata dalam gram gaya $(\mathrm{mN})$.

$\mathrm{B}=$ jumlah lembar contoh uji yang dipergunakan pada saat pengujian.

\section{HASIL DAN PEMBAHASAN}

\section{Proses Pengujian Ketahanan Sobek}

a. Definisi

Ketahanan sobek adalah gaya dalam gram gaya (gf) atau milinewton (mn) yang diperlukan untuk menyobek kertas pada kondisi standar. Indeks sobeknya adalah ketahanan sobek kertas dalam miliNewton $(\mathrm{mN})$ dibagi dengan gramatur kertas dalam gram meter persegi.

\section{b. Metode pengujian}

Metode yang digunakan penulis yaitu metode elmonderf

c. Cara pengambilan sampel

1) Sampel uji dipersiapkan sesuai dengan SII 04444 81, cara pengambilan contoh kertas dan karton dan dipotong dengan ukuran panjang $76 \pm 2 \mathrm{~mm}$ dan lebar $64,0 \pm 0,15 \mathrm{~mm}$

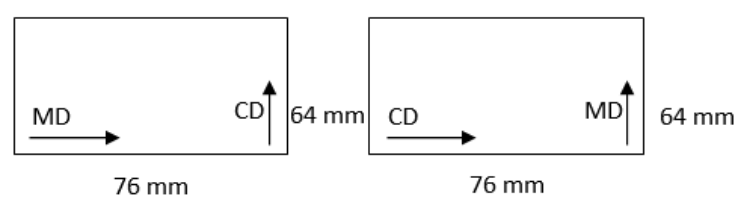

Gambar 4. Sampel uji MD dan CD

2) Menyiapkan 10 atau lebih lembar contoh uji masing - masing untuk arah mesin (MD) dan silang mesin (CD).

3) Untuk menjamin ketelitian hasil uji diperoleh, maka contoh lebih dahulu harus disimpan dalam ruangan sesuai dengan SII 0388 - 80, kondisi ruangan pengujian untuk lembaran pulp, kertas dan karton, selama waktu tertentu selama 24 jam. 
4) Untuk keperluan pengendalian proses, misalnya apabila contoh langsung diambil dari mesin kertas maka penyimpanan dalam ruangan kondisi standar tidak diperlukan.

\section{d. Prinsip uji}

Ketahanan sobek adalah daya tahan kertas atau tenaga yang dibutuhkan untuk merobek suatu kertas. Daya tahan sobek yang satu dengan yang lainnya tidaklah sama. Semakin kuat kertas maka semakin tinggi nilai ketahanan sobeknya. Arah serat mempengaruhi nilai ketahan sobek dimana arah lintang mempunyai nilai yang tingg daripada arah mesin. Pengujian ketahanan sobek dapat dilakukan pada alat tearing tester dengan satuan mili newton $(\mathrm{mn})$ atau gaya gram (gf).

\section{e. Cara pengujian}

1) Menyiapkan sektor pendulum pada kedudukan awal dan jarum penunjuk pada titik $0($ nol)

2) Memasang 4 lembar contoh uji pada alat penjepit dengan posisi vertikal searah lebar contoh uji

3) Melakukan penyobekan awal dengan mempergunakan pisau yang tersedia pada alat tersebut, higga jarak sobek yang tersisa 43,0 $\mathrm{mm}$.

4) Lalu Menekan penahan alat pendulum sedemikian rupa sehingga pendulum menganyun bebas.
5) Dan tahanlah pendulum setelah sobekan menyeluruh dan kembalikan pada kedudukan awal tanpa mengganggu kedudukan jarum penunjuk.

6) Hasil pengujian dicatat sesuai dengan angka pada skala yang ditunjukan oleh jarum petunjuk.

Dari hasil ini dapat diperkirakan beberapa lembar contoh uji yang harus dipasang pada pengujian yang sebenarnya. Apabila satu lembar contoh uji sudah menghasilkan angka ketahanan sobek lebih dari 60, maka pada sektor pendulum perlu dipasang beban.

\section{Data Hasil Pengujian}

Berdasarkan pengujian yang penulis lakukan di Laboratorium Pengujian Bahan Grafika Politeknik Negeri Media Kreatif Jakarta, penulis mendapatkan hasil yang berbeda antara arah serat MD dan CD untuk masingmasing kertas yang diuji dengan kondisi suhu pada saat pengujian yaitu $\pm 33^{\circ} \mathrm{C}$. Setelah melakukan pengujian beberapa kali, penulis mendapatkan hasil uji yang diinginkan. Berikut ada hasil data pengujian ketahanan sobek kertas mattpaper produk New Victory Luxe dan Nevia.

Tabel 1. Data pengujian ketahanan sobek kertas Mattpaper 120 gram $/ \mathrm{m}^{2}$ produk New Victory Luxe arah serat MD

\begin{tabular}{|c|c|c|c|c|}
\hline No. & Hasil & Daya & & \\
Uji & Tahan & $(\mathrm{x}-\bar{x})$ & $(\mathrm{x}-\bar{x})^{\mathbf{2}}$ \\
\hline
\end{tabular}




\begin{tabular}{|c|c|c|c|c|}
\hline & & $\begin{array}{c}\text { Sobek } \\
(\mathrm{mN})\end{array}$ & & \\
\hline 1 & 250 & 1000 & -91 & 8281 \\
\hline 2 & 250 & 1000 & -91 & 8281 \\
\hline 3 & 270 & 1080 & -11 & 121 \\
\hline 4 & 260 & 1040 & -51 & 2601 \\
\hline 5 & 280 & 1120 & 29 & 841 \\
\hline 6 & 280 & 1120 & 29 & 841 \\
\hline 7 & 290 & 1160 & 69 & 4761 \\
\hline 8 & 280 & 1120 & 29 & 841 \\
\hline 9 & 270 & 1080 & -11 & 121 \\
\hline 10 & 280 & 1120 & 29 & 841 \\
\hline 11 & 280 & 1120 & 29 & 841 \\
\hline 12 & 270 & 1080 & -11 & 121 \\
\hline 13 & 280 & 1120 & 29 & 841 \\
\hline 14 & 280 & 1120 & 29 & 841 \\
\hline 15 & 270 & 1080 & -11 & 121 \\
\hline$\Sigma x$ & & 16360 & & 30295 \\
\hline $\bar{x}$ & & 1091 & & \\
\hline
\end{tabular}

$$
\begin{array}{ll} 
& =\sqrt{\frac{30295}{15-1}} \\
& =\sqrt{\frac{30925}{14}} \\
& =\sqrt{2208,928} \\
& =47 \\
& =\frac{ \pm \mathrm{SD}}{\bar{x}} \times 100 \% \\
& =\frac{47}{1091} \times 100 \% \\
& =4,3
\end{array}
$$

\begin{tabular}{|c|c|c|c|c|}
\hline No. & $\begin{array}{c}\text { Hasil } \\
\text { Uji }\end{array}$ & $\begin{array}{c}\text { Daya } \\
\text { Tahan } \\
\text { Sobek } \\
(\mathrm{mN})\end{array}$ & $(\mathrm{x}-\bar{x})$ & $\begin{array}{c}(\mathrm{x}-\bar{x} \\
)^{2}\end{array}$ \\
\hline 1 & 320 & 1280 & 136 & 18496 \\
\hline 2 & 280 & 1120 & -24 & 576 \\
\hline 3 & 290 & 1160 & 16 & 256 \\
\hline 4 & 280 & 1120 & -24 & 576 \\
\hline 5 & 270 & 1080 & -64 & 4096 \\
\hline 6 & 270 & 1080 & -64 & 4096 \\
\hline 7 & 280 & 1120 & -24 & 576 \\
\hline 8 & 290 & 1160 & 16 & 256 \\
\hline 9 & 280 & 1120 & -24 & 576 \\
\hline 10 & 300 & 1200 & 56 & 3136 \\
\hline 11 & 290 & 1160 & 16 & 256 \\
\hline 12 & 300 & 1200 & 56 & 3136 \\
\hline 13 & 280 & 1120 & -24 & 576 \\
\hline 14 & 280 & 1120 & -24 & 576 \\
\hline 15 & 280 & 1120 & -24 & 576 \\
\hline$\Sigma \mathrm{X}$ & & 17160 & & 37760 \\
\hline
\end{tabular}

Tabel 2. Data pengujian ketahanan sobek kertas Mattpaper 120 gram $/ \mathrm{m}^{2}$ produk New Victory Luxe arah serat CD 
Sumber : Penulis

Keterangan :

Contoh perhitungan data 1 :

Ketahanan sobek $=\frac{16 \times A}{B}=\frac{16 \times 320}{4}=1280$

$$
\begin{aligned}
\text { DTS rata-rata }(\bar{x}) & =\frac{\Sigma \mathrm{x}}{n} \\
& =\frac{17160}{15} \\
& =1144 \mathrm{mN} \\
\pm \mathrm{SD} & =\sqrt{\frac{\Sigma(\mathrm{x}-\bar{x})^{2}}{n-1}} \\
& =\sqrt{\frac{37760}{15-1}} \\
& =\sqrt{\frac{37760}{14}} \\
& =\sqrt{2697,142} \\
& =51,93 \\
& =\frac{ \pm \mathrm{SD}}{\bar{x}} \times 100 \% \\
& =\frac{51,93}{1144} \times 100 \% \\
& =4,53
\end{aligned}
$$

\begin{tabular}{|c|c|c|c|c|}
\hline 4 & 260 & 1040 & -61 & 3721 \\
\hline 5 & 270 & 1080 & -21 & 441 \\
\hline 6 & 280 & 1120 & 19 & 361 \\
\hline 7 & 270 & 1080 & -21 & 441 \\
\hline 8 & 270 & 1080 & -21 & 441 \\
\hline 9 & 280 & 1120 & 19 & 361 \\
\hline 10 & 280 & 1120 & 19 & 361 \\
\hline 11 & 280 & 1120 & 19 & 361 \\
\hline 12 & 280 & 1120 & 19 & 361 \\
\hline 13 & 280 & 1120 & 19 & 361 \\
\hline 14 & 270 & 1080 & -21 & 441 \\
\hline 15 & 270 & 1080 & -21 & 441 \\
\hline$\Sigma \mathrm{x}$ & & 16280 & & 19255 \\
\hline $\bar{x}$ & & 1101 & & \\
\hline
\end{tabular}

\section{Sumber : penulis}

$$
\begin{aligned}
\operatorname{DTS} \text { rata-rata }(\bar{x}) & =\frac{\Sigma \mathrm{x}}{n} \\
& =\frac{16280}{15} \\
& =1101 \mathrm{mN}
\end{aligned}
$$$$
\pm \mathrm{SD} \quad=\sqrt{\frac{\sum(\mathrm{x}-\bar{x})^{2}}{n-1}}
$$$$
=\sqrt{\frac{19255}{15-1}}
$$$$
\text { arah serat MD }
$$

\begin{tabular}{|c|c|c|c|c|}
\hline & Hasil & $\begin{array}{c}\text { Daya } \\
\text { Tahan } \\
\text { Sobek } \\
(\mathrm{mN})\end{array}$ & $\begin{array}{c} \\
(\mathrm{x}-\bar{x})\end{array}$ & $(\mathrm{x}-\bar{x})^{2}$ \\
\hline 1 & 260 & 1040 & -61 & 3721 \\
\hline 2 & 260 & 1040 & -61 & 3721 \\
\hline 3 & 260 & 1040 & -61 & 3721 \\
\hline
\end{tabular}$$
=\sqrt{\frac{19255}{14}}
$$$$
=\sqrt{1375,357}
$$$$
=37,08
$$

$\%$ Variasi

$$
=\frac{ \pm \mathrm{SD}}{\bar{x}} \times 100 \%
$$




$$
\begin{aligned}
& =\frac{37,08}{1101} \times 100 \% \\
& =3,36
\end{aligned}
$$

Tabel 4. Data pengujian ketahanan sobek kertas Mattpaper 120 gram $/ \mathrm{m}^{2}$ produk Nevia $\pm \mathrm{SD}$

\begin{tabular}{|c|c|c|c|c|}
\hline No. & $\begin{array}{c}\text { Hasil } \\
\text { Uji }\end{array}$ & $\begin{array}{l}\text { Daya } \\
\text { Tahan } \\
\text { Sobek } \\
(\mathrm{mN})\end{array}$ & $(\mathrm{x}-\bar{x})$ & $(\mathrm{x}-\bar{x})^{2}$ \\
\hline 1 & 360 & 1440 & -29 & 841 \\
\hline 2 & 380 & 1520 & 51 & 2601 \\
\hline 3 & 370 & 1480 & 11 & 121 \\
\hline 4 & 360 & 1440 & -29 & 841 \\
\hline 5 & 370 & 1480 & 11 & 121 \\
\hline 6 & 360 & 1440 & -29 & 841 \\
\hline 7 & 350 & 1400 & -69 & 4761 \\
\hline 8 & 370 & 1480 & 11 & 121 \\
\hline 9 & 360 & 1440 & -29 & 841 \\
\hline 10 & 360 & 1440 & -29 & 841 \\
\hline 11 & 390 & 1560 & 91 & 8281 \\
\hline 12 & 370 & 1480 & 11 & 121 \\
\hline 13 & 370 & 1480 & 11 & 121 \\
\hline 14 & 380 & 1520 & 51 & 2601 \\
\hline 15 & 360 & 1440 & -29 & 841 \\
\hline$\Sigma \mathrm{x}$ & & 22040 & & 23895 \\
\hline$\overline{\bar{x}}$ & & 1469 & & \\
\hline
\end{tabular}
arah serat $\mathrm{CD}$

Sumber : penulis

Keterangan :

Contoh perhitungan data 1 :

Ketahanan sobek $=\frac{16 \times A}{B}=\frac{16 \times 360}{4}=1440$

DTS rata-rata $(\bar{x})=\frac{\Sigma x}{n}$

$$
\begin{aligned}
& =\frac{22040}{15} \\
& =1469 \mathrm{mN} \\
& =\sqrt{\frac{\sum(\mathrm{x}-\bar{x})^{2}}{n-1}} \\
& =\sqrt{\frac{23895}{15-1}} \\
& =\sqrt{\frac{23895}{14}} \\
& =\sqrt{1706,785} \\
& =41,31 \\
& =\frac{ \pm \mathrm{SD}}{\bar{x}} \times 100 \% \\
& =\frac{41,31}{1469} \times 100 \% \\
& =2,81
\end{aligned}
$$

\section{Perbandingan Hasil Uji Ketahanan Sobek}

Ketahanan sobek adalah gaya dalam gram gaya (gf) atau milinewton $(\mathrm{mN})$ yang diperlukan untuk menyobek kertas pada kondisi standar (SNI 14-0091-1998). Sedangkan indeks sobek lembaran kertas merupakan hasil bagi dari ketahanan sobek dengan grammatur. Standar tersebut menetapkan cara uji ketahanan sobek lembaran kertas menurut metode Elmendorf. Tabel 5. Hasil pengujian Ketahanan Sobek kertas Mattpaper 120 gram $/ \mathrm{m}^{2}$ produk New Victory Luxe dan Produk Nevia

\begin{tabular}{|c|c|c|}
\hline $\begin{array}{c}\text { Jenis } \\
\text { kertas }\end{array}$ & MD & CD \\
\hline
\end{tabular}




\begin{tabular}{|l|c|c|}
\hline New & $1091 \pm 47$ & $1144 \pm$ \\
Victory & $(4,3 \%)$ & $51,9(4,5 \%)$ \\
Luxe & & \\
\hline Nevia & $1101 \pm$ & $1469 \pm$ \\
& 37,08 & $41,3(2,8)$ \\
& $(3,3 \%)$ & \\
\hline
\end{tabular}

Ketahanan sobek dipengaruhi oleh ukuran serat, jumlah ikatan antar serat, grammatur, kelembaban, kadar air, arah serat, perekat pada kertas. Arah CD (Cross direction) membutuhkan gaya yang lebih besar dibandingkan dengan MD (Machine direction) untuk membuat kertas sobek.

Hasil pengujian kedua produk kertas tersebut menyebutkan nilai ketahanan sobek arah serat Cross direction (CD) produk New Victory Luxe adalah $1144 \mathrm{mN}$, sedangkan nilai ketahanan sobek arah serat CD produk Nevia adalah $1469 \mathrm{mN}$.

Demikian pula nilai ketahanan sobek arah serat Machine direction (MD) produk New Victory Luxe adalah $1091 \mathrm{mN}$, sedangkan nilai ketahanan sobek arah serat MD produk Nevia adalah $1101 \mathrm{mN}$. Pada arah serat MD, kedua produk tersebut hanya memiliki selisih yang sangat tipis, yakni hanya sekitar $10 \mathrm{mN}$. Berbeda pada arah serat $\mathrm{CD}$ yang memiliki perbandingan yang sangat signifikan, yakni sekitar $325 \mathrm{mN}$. Maka dari itu, dilihat berdasarkan tabel di atas dapat disimpulkan bahwa kertas produk Nevia lebih unggul dan lebih baik pada ketahanan sobeknya dibandingkan dengan kertas produk New Victory Luxe.

\section{KESIMPULAN}

Berdasarkan pembahasan yang telah dilakukan pada bab sebelumnya dan didukung dengan data yang valid dan sesuai, penulis mendapatkan jawaban atas rumusan masalah diatas. Jawaban tersebut penulis rangkum dalam bentuk simpulan dibawah ini: a. Metode untuk melakukan pengujian terhadap ketahanan sobek kertas dua jenis produk kertas diatas adalah dengan menggunakan metode Elmendorf.

b. Hasil pengujian ketahanan sobek kertas produk New Victory Luxe arah serat MD yaitu $1091 \mathrm{mN}$ dan arah serat CD yaitu 1144 $\mathrm{mN}$, sedangkan produk Nevia arah serat MD yaitu $1101 \mathrm{mN}$ dan arah serat CD yaitu 1469 $\mathrm{mN}$.

c. Berdasarkan hasil data pengujian pada bab sebelumnnya didapatkan perbandingan nilai ketahanan sobek kertas produk Nevia lebih unggul dibandingkan dengan kertas produk New Victory Luxe, baik pada arah serat MD maupun arah serat CD.

\section{Saran}

Setelah penulis melakukan penyusunan Penelitian, penulis memiliki beberapa saran untuk perusahaan dan institusi pendidikan, yaitu sebagai berikut :

\section{Perusahaan}


1. Hasil cetakan dipengaruhi oleh beberapa faktor, salah satunya yaitu bahan baku. Untuk mendapatkan hasil cetakan yang berkualitas maka gunakanlah kertas yang berasal dari bahan baku yang berkualitas pula dalam pembuatan nya. Sehingga mendapatkan hasil cetakan yang baik.

2. Sebelum memilih kertas yang akan digunakan untuk mencetak, sebaiknya dilakukan pengujian material/bahan terlebih dahulu. Hal ini bertujuan untuk mengurangi masalah yang mungkin terjadi saat proses produksi.

\section{REFERENSI}

Dameria, Anne. 2007. Kertas dan Karton: Buku Basic Printing. Gramedia.

Djaiz, Mukhyidin. 2010. Pengantar Ilmu
Grafika. Jakarta: Politeknik Negeri Media Kreatif.

Djamara, Tabrani. 2007. Glossarium Grafika. Disunting oleh Bambang Purwanto. Jakarta: Pusat Grafika Indonesia.

Prabowo, Erry Tri. 2018. "Laporan Praktek Industri di PT. Aksara Grafika Pratama”. Jakarta.

SNI 0436. 2009. Kertas - Cara Uji Ketahanan Sobek - Metode Elmendorf

Tambunan, Lilis Rosmaniar. 2018. Keasaman $p H$ : Pengantar Kimia Dasar. Penerbit: Deepublish.

Tavianto, Tedy dan Efnyta Muchtar. 2011. Pengetahuan Kertas dan Cara Pengujiannya. Jakarta: Buku Ajar Ilmu Bahan Grafika 